\title{
Quality Personnel the Bane of the University Students Participation in National Competition?: The Case of Kenya
}

\author{
Janet Chumba (Corresponding author) \\ University of Nairobi, Kenya \\ E-mail:jmchumba@gmail.com \\ Simon Munayi \\ University of Nairobi, Kenya \\ Jacob S. Nteere \\ University of Nairobi, Kenya
}

Received: December 9, 2019

Accepted: January 17, $2020 \quad$ Published: February 19, 2020

doi:10.5296/jet.v7i1.16008

URL: http://dx.doi.org/10.5296/jet.v7i1.16008

\begin{abstract}
Kenyan university students have performed relatively poorly compared to their counterparts in Australia and the United Kingdom when it has come to International sports participations. Could this be attributed to the personnel handling sports at the Kenyan Universities? This study went out to look at the perceptions of the students participating in sports at public and private universities in Kenya. Further, the study went out to look at the qualifications and quantification of personnel in both private and public universities in Kenya. The study used a descriptive research design. A questionnaire was used on 268 students responded. An interview schedule was used on 10 directors and chairmen of sports directorates and departments. A further 28 sports personnel in public and private universities in Kenya were also used in the study. The results indicate that personnel in Kenyan University had diverse field of training. There was need to arrest this diversity and create a more focused sports trained personnel if the Kenyan university expect to make the same impact as that of Australia and the United Kingdom in international sport. Results also show that private universities in Kenya have better and available personnel than the public universities.
\end{abstract}

Keywords: Personnel, Perceptions, Qualifications, Diversity, Performance

\section{Introduction}

Different social cultural agents continue to influence youth in sports (Woods, 2007). In 
order to excel in international sports competitions, many countries of the world have relied on educational institutions for early identification and development of sports talent (Woodruff $\&$ Schallert, 2008). This is largely attributable to the fact that the largest proportions of youth that have the potential to post outstanding performances are readily available in educational institutions. Indeed, there is abundant evidence of student-athletes from the developed world who have participated and attained impressive performances in international sports competitions, including the Olympic Games (Rintaugu, Mwisukha, \& Munayi, 2011). However, the available statistics show that student-athletes from educational institutions in Africa have not made much significant impact in terms of participation and performance at the major international sports events (Mwisukha \& Wanderi, 2014).

Wyllen and Lavallen (2004) in their study noted that the Australian national team has been presenting students at the Olympic Games since 2004. The same research has shown that in the 2004 the team presented 112 students from 32 institutions of higher learning, these included University of Sydney 12 students, University of New South Wales 12 students and University of Technology Sydney/ University of Melbourne 9 students each. In the same year these students won 19 medals out of the 49 medals won by the whole Australian team or 39\% of the total team tally. In 2008 Beijing Olympics, the Australian team selected 201 students. This was $46 \%$ of the total team. They came from 36 higher education institutions. This included University of Queensland, University of West Australia and University of Melbourne. The students won 26 medals out of the total 46 medals won by the team these constituted to $57 \%$ of the total team tally. In London 2012 Australia presented 164 students, these were $40 \%$ of the total team. The students won 22 medals out of the 35 medals won by the team. What is the situation in Kenya? This study goes out to discover the situation in Kenya.

Team Great Britain has been tracking the performance of their University student athletes at the Olympic Games since the Barcelona Olympics in 1992. The medal standings for these teams show that $65 \%$ of the medals list has been won by university students. This compares to $31 \%$ of the general population. Universities that have made it in Great Britain include University of Oxford, University of Cambridge, Loughborough University, Oxford Brookes, University of Edinburgh and Bath University (De Bossheret all 2008).

Allen (1997) however observed that female university athletes have different influence from their trainers. The trainers of the female teams have created an environment that puts more emphasis on the importance of academic results among female university athletes. Specifically, female university athletes have a positive influence from their trainers in both their sports and academic work. This study went out to discover if personnel in both public and private universities in Kenya play a role in influencing students' participation in sports for representation at the international level.

\section{Objectives}

This study sought to find out if personnel at the universities in Kenya play a role in sports participation in institutions of higher learning in Kenya for representation at the international competitions. 


\section{Methodology}

The research used the descriptive survey design. Sampling was purposive in nature; respondents were sportsmen and sportswomen of Kenyan university. Directors and chairmen of sports directorates/departments and personnel working in the sports directorates/ departments were also used as respondents. Questionnaires and interview schedules were used to collect data. Interviews were held using a one on one session to get the responses. This study targeted students and sports personnel involved in sports at the university. Universities in Kenya are categorized either as public or private. About 5\% of the students who enroll in universities participate in either scholastic or interscholastic sports translating to a target population of 10,000 (Munayi, 2014). The body mandated nationally to run sports is the Kenya University Sports Association (KUSA). For ease of operations and logistics KUSA has divided all universities in Kenya into six conferences. Three conferences were purposively sampled, namely; Nairobi conference, Western conference and KUSA central. Further, fifty percent from each gender were sampled. This translated to 300 students. Out of the three hundred, 268 students filled their questionnaires. The study also involved personnel who work in sports directorates and departments, these personnel were designated directors, chairmen, games tutors and sports coaches.

Questionnaires and interview schedules were used as a tool for data collection. The researcher personally delivered questionnaire to the respondents and waited for them to be filled. Comparison of means was done. A t-test resulting in a computed t-statistics for hypothesis testing based on personnel and university category was done.

\section{Data Analysis and Discussion}

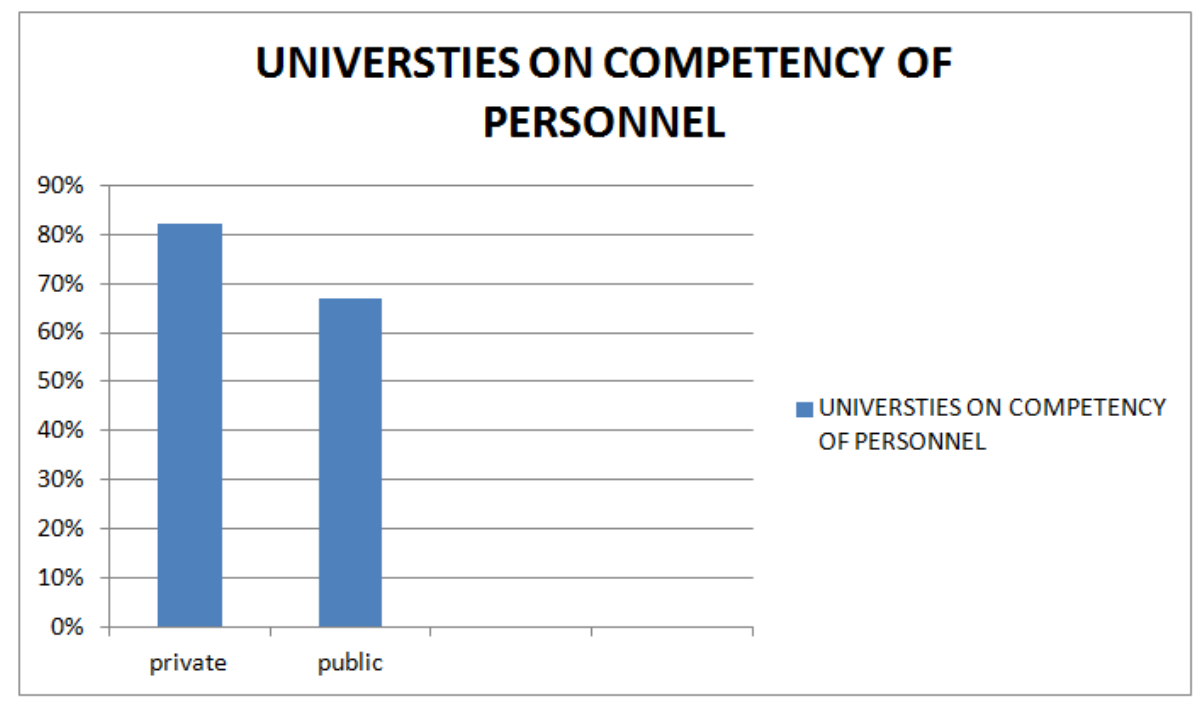

Figure 1. Competency of Personnel

Private universities had a higher number of students agreeing that their personnel were competent enough. $82 \%$ of the students in private universities in Kenya agreed while their counterpart in public with $67 \%$ agreeing that they had competent personnel to handle sports. The results reveal that private universities in Kenya have more competent personnel compared to public universities yet a larger number of student population at the universities 
in Kenya is by public universities. This could be the reason why there is under-representation of Kenyan university students at the international event.

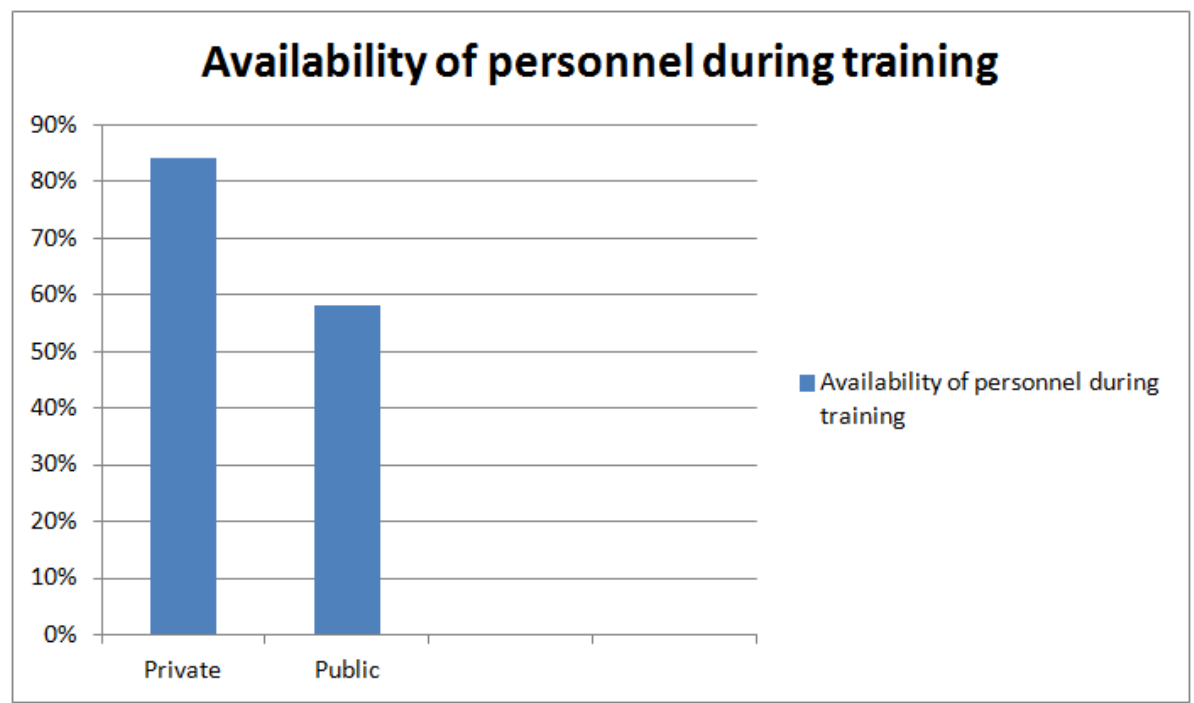

Figure 2. Availability of Personne

From the findings above on Figure 2, a higher proportion of respondents from private universities agreed that their coaches and trainers were present during training. $84 \%$ of sports students in private universities agreed that their trainers were present during training while on the other hand $54 \%$ of their counterpart in public universities agreed that their trainers were present for training. The same pattern is repeating itself, public universities in Kenya admit a higher percentage of students compared to public universities. If personnel handling sports at the public universities are not present during training, then this could be the reason for under-representation at the international level.

Table 1. Qualification of sports personnel at the Kenyan universities

\begin{tabular}{|c|c|c|c|c|c|}
\hline University & Designation & Male & Female & Qualification & Specialization \\
\hline 1 & AGT, and GT & 4 & 1 & Bachelors & P.E. \\
\hline 2 & SGT,GT, coach & 3 & 0 & Degree, Diploma & P.E.\&sports management \\
\hline 3 & Coaches & 2 & 0 & Form Four & Soccer \\
\hline 4 & Director, Senior \&assistant sports officer & 2 & 1 & MSC, BSC & P.E.\& sports science \\
\hline 5 & Sports coordinator, coaches & 13 & 1 & Bachelors, certificates & Sports science, sports \\
\hline 6 & Senior Games Tutor,coaches, EF & 6 & 2 & Bachelors, diploma & P.E. \\
\hline 7 & Director, coaches & 9 & 1 & MBA & Business administration \\
\hline 8 & Coaches, sport officer & 5 & 1 & Bachelors, certificates & P.E, sports \\
\hline 9 & Trainer, coaches & 7 & 1 & Masters,Bachelors, & Games \\
\hline 10 & Sports tutor, coordinator & 1 & 1 & Degree & Biology, P.E. \\
\hline
\end{tabular}


From table 1 above, it is evident that the male gender dominated in all categories. From the sports personnel that participated in the study director/chairmen of directorates/departments SGT (senior games tutors), GT (games tutors), AGT (assistant games tutors) and coaches only $15 \%$ (9) were of the female gender, while $85 \%$ (50) were of the male gender. Generally the male gender dominated in sports management in sports management and staff coaching across both public and private universities.

The researchers carried out an interview in ten public and private universities. The study revealed that out of the ten sampled universities sports directors and chairmen, eight universities $(80 \%)$ were headed by the male gender, but the distribution of the gender of directors and chairmen did not differ by university category. Similar gender disparity exists among other members of staff in the sports directorates and department.

The academic qualification of the sixty one (61) coaching staff revealed that two members of the coaching staff had qualifications that were not sports related. The researcher concluded that the limited number of personnel at both public and private universities in Kenya and gender imbalance could be part of the contributing factors of under-representation of Kenyan university students at the international sports competition like the Olympic Games.

\section{Conclusion}

- Most universities are headed and coached by the male gender which could be attributed to a cultural norm which associates male with sports and female with family and home making. This norm has permeated among university sports personnel and students impairing female student representation at the national and international levels.

Coaches in private universities are easily accessible and present during training at the same time more qualified than public universities in Kenya.

- Coaches in private universities in Kenya are viewed by students as well qualified than coaches in public universities.

\section{Recommendation}

- Public universities should invest in recruiting more personnel to man sports departments. The number of personnel in charge of sports in both public and private universities is too small compared to the student population.

- All universities need to employ coaches that are qualified in their area of study. Coaching personnel should also be vetted for employment. Most personnel in sports directorates and department are not qualified in their area of study. A number of universities in Kenya offer sports related courses, this means that they are not enough for the Kenyan market.

\section{References}

Allen, M. S. (1997). The academic socialization of intercollegiate athletes. Unpublished doctoral dissertation, University of Connecticut.

De Bosscher, V., Bingham, J., Shibe, S., Van Bttenburg, M., \& De Knop. (2008). The Global Sporting Arm Race: An International Comparative Study on Sport Policy, Factors 
Leading to International Sporting Success. Oxford: Meyer and Sport.

Munayi, S. (2014). Management of Sports in Kenyan Public Universities- Emerging Trends. Unpublished All African University Games conference, University of Nairobi 2014.

Mwisukha, \& Wanderi. (2014). Participation and Performance of Student-Athletes at Olympic Games; Lesson for Universities in Africa. International Journal of Humanities and Social Science, 1.

Rintaugu, E. G., Mwisukha, A., \& Munayi, S. (2011). Sports: On the right track. In S. K. Njonjo, A. Kitonga, \& P. Awour (Eds.), Youth research compendium. Institute of Economic Affairs, Nairobi.

Woodruff, A. L., \& Schallert, D. L. (2008). Studying to play, playing to study: Nine collegestudent-athletes' motivational sense of self. Contemporary Educational Psychology, 33(1), 34-57.

Woods, R. B. (2007). Social issues in sport. Champaign, IL: Human Kinetics.

Wyllenman, P., \& Laelle, D. (2004). Athtic Retirement: A Cross- National Comparison of Elite French and Swedish Athletes. Psychology of Sports and Exercise, 8(2007), 101-108.

\section{Copyright Disclaimer}

Copyright reserved by the author(s).

This article is an open-access article distributed under the terms and conditions of the Creative Commons Attribution license (http://creativecommons.org/licenses/by/3.0/). 